\title{
Stages and Muddles: The House of Lords Act 1999
}

\author{
Parliamentary History (2011), vol.30, no.1, pp.101-113.
}

\author{
Alexandra Kelso \\ Department of Politics and International Relations \\ School of Social Sciences \\ University of Southampton \\ Southampton SO17 1BJ
}

Email: $\underline{\text { A.Kelso@soton.ac.uk }}$

\begin{abstract}
As one of the most significant pieces of constitutional legislation enacted in the last century, the House of Lords Act 1999 radically reformed the membership of the second chamber of the Westminster parliament by removing almost all the hereditary peers who sat there. The act formed a key part of the constitutional reform agenda of the Labour government elected in 1997, but despite its massive majority in the house of commons, eliminating the hereditary peerage proved far harder than might first have been imagined. This article seeks to explore the events surrounding that act, the political machinations and deals leading up to it, the course of the legislation through parliament, and the intricacies of the process involved in securing constitutional reform of this magnitude. It concludes by examining the consequences of the act for subsequent attempts at further second chamber reform during the rest of the Labour government's time in office.
\end{abstract}


The House of Lords Act 1999 was one of the most significant pieces of constitutional legislation enacted during the twentieth century, and it (partially) fulfilled a goal that persisted as a key part of the Lords reform agenda since the Parliament Act 1911: that is, the removal of the hereditary peers from the second chamber. In locating the Act within the context of a two-stage approach to Lords reform, the Labour government believed it could remove the most democratically offensive part of the chamber, and then proceed to identify a clear position with respect to compositional reform behind which the party could unite. However, the decade that followed the Act was marked by policy uncertainty and confusion, which rendered the subsequent processes of Lords reform muddled and rudderless, and ironically undermined what was, in fact, a major constitutional change with lasting and substantial consequences for Westminster politics.

\section{The rationale for reform}

The Labour Party has, throughout its history, had a highly changeable policy towards the House of Lords, and as late as 1983 was committed in its general election manifesto to abolishing the chamber altogether, and to redesigning Westminster as a unicameral parliament. ${ }^{1}$ The Conservative-dominated hereditary peerage in the upper chamber proved in the post-war era to be a source of considerable frustration to Labour governments, both on points of policy and on points of principle. Not only did a hereditary chamber offend the democratising instincts of the Labour Party, but the substantially outnumbered Labour peers in the Lords found themselves easily voted down, regardless of the value of the legislative points they sought to make. ${ }^{2}$ In the 1970 s and 1980 s, the general view held in the Labour Party was that a second chamber could too easily frustrate the wishes of a committed government of the left, and that, rather than expend energy and political capital on reforming it, the far more sensible option was to simply abolish the upper house, and focus instead on reforming the various practices and procedures of the democratically elected lower house in which the government sat.

By 1992, however, the party's policy had changed markedly, and unicameralism was abandoned in favour of support for an elected upper house. ${ }^{3}$ 
This modification reflected a growing commitment within the Labour Party to constitutional change more broadly, spearheaded by Labour leader John Smith, and demonstrated by the then Shadow Chancellor, Gordon Brown, arguing for a new constitutional settlement that comprised reform of the 'indefensible' unelected Lords, but which also mapped out increasingly coherent plans for devolution, incorporation of the ECHR, and freedom of information. ${ }^{4}$ By 1997, these plans had become even further embedded into the Labour Party's policy infrastructure, and the commitment to 'cleaning up' politics and facilitating democratic renewal formed a cornerstone of the New Labour brand promoted by Tony Blair and Gordon Brown. Policy commitments on the House of Lords received considerably more space in the 1997 manifesto than in previous years, yet also demonstrated that yet another shift in emphasis had occurred since 1992:

The House of Lords must be reformed. As an initial, self-contained reform, not dependent on further reform in the future, the right of hereditary peers to sit and vote in the House of Lords will be ended by statute. This will be the first stage in a process of reform to make the House of Lords more democratic and representative ... A committee of both Houses of Parliament will be appointed to undertake a wide-ranging review of possible further change and then to bring forward proposals for reform. ${ }^{5}$

The fundamental point to note with respect to the 1997 Labour Party manifesto, then, is that it said nothing about the need to create an elected second chamber. The commitment to reform was restricted to getting rid of the hereditary peers. Whereas the 1992 manifesto clearly stated the party's intent to create an elected House, the 1997 manifesto said nothing of the sort, instead using the rather less explicit language about making the chamber 'more democratic and representative', but avoiding entirely any declared statement of what this might mean in practice. The pragmatism of the manifesto was that it substantially shifted the reform terrain by committing to a two-stage process. For most of the twentieth century, debates about House of Lords reform were plagued by a contradictory certainty: certainty that the hereditary principle was indefensible in the context of a modern representative democracy, and the concomitant certainty 
that no one could agree on what should replace it. By 1997, the Labour leadership had decided that the one way to get beyond this impasse was simply to abolish the right of the hereditary peers to sit and vote in parliament, and thus eradicate the most offensive aspect of the upper chamber, and only then start thinking about the far trickier matter of broader compositional reform. The new House of Lords policy also indicated that removing the hereditary peers did not mean that further reform was either necessary or guaranteed, a position that would be a source of considerable political annoyance for the party once in power.

As far as House of Lords reform was concerned, then, the 1997 Labour Party manifesto, and its two-stage approach, was a masterclass in political realism. It acknowledged the lessons of the past one hundred years, and the failure to find agreement on what a reformed composition should look like, but committed nevertheless to removing the hereditary peers, and thus easily demonstrating the incoming government's democratic credentials. The Labour Party had already tried in government to proceed with holistic second chamber reform in 1968-69, and do so in a cross-party fashion, an endeavour which had ended in failure and embarrassment. If it wished to secure any kind of reform, then, it needed to be able to do so by relying only on the support of its own members. A two-stage approach enabled a future Labour government to take advantage of the support within its own party for removing the hereditary peers, and only then think about a cross-party basis for future reform once that first bridge had been successfully crossed. Indeed, simply getting rid of the hereditary peers seemed like a relatively straight-forward piece of constitutional reform, given how hard it had become to defend the hereditary principle. Yet, as the Labour government found out, it was neither easy nor straight-forward, and crucially, it was not without political costs.

Having been out of office for almost two decades, the new Labour government elected in 1997 had a substantial programme of reform it wished to implement, and its constitutional change agenda was arguably unlike that ever before pursued by an incoming administration. Consequently, with its capacity for action initially constrained by what could be secured in terms of legislation in the first parliamentary session, the government necessarily had to triage its commitments, and by far the most important of its constitutional policies was 
devolution and, to a lesser extent, human rights. As a result, a significant portion of the first session of 1997-98 was accounted for legislating for these policies, ${ }^{6}$ and the cabinet decided that reform of the House of Lords would be delayed until the second session of 1998-99. The decision to delay was a key determining factor in the subsequent course of House of Lords reform. The magnitude of the defeat suffered by the Conservative Party in 1997 left it in a state of stunned disarray in the House of Commons, and in almost no position to offer meaningful opposition to anything that the Labour government proposed in its first year. ${ }^{7}$ It is very likely that, had the government proceeded to legislate for the removal of the hereditary peers in its first parliamentary session in power, the story of the House of Lords Act recounted here would be rather different. As it was, however, the government did delay, and in so doing, allowed the Conservative opposition time to catch its breath and prepare for battle.

\section{Negotiating the reform process}

Action to fulfil the manifesto commitment began with the 1998 Queen's Speech, which promised a bill 'to remove the right of hereditary Peers to sit and vote in the House of Lords', with the stipulation once more being made that this would be 'the first stage in a process of reform to make the House of Lords more democratic and representative. ${ }^{8}$ The Queen's Speech also diverged from what had been promised in the manifesto, by announcing the establishment of a Royal Commission 'to review further changes and speedily to bring forward proposals for reform.' The manifesto had in fact pledged a joint committee of both Houses, which is a quite different institutional creature to a Royal Commission, with the latter traditionally taking far longer to reach agreed reports, and also being somewhat easier for governments to manage because of the different dynamics of the power of appointment.

The government's plan to remove the hereditary peers and only then consider further compositional reform of the upper chamber may well have been the best option in terms of actually securing change, but it nevertheless afforded the opposition a prime strategy for attack. William Hague, Leader of the Opposition, characterised the government's plans for removing the hereditary peers as 'constitutional vandalism', and argued that people would want to hear 
the conclusions of the Royal Commission before proceeding with stage one of reform. Hague thus exploited the soft underbelly of the two-stage process and laid the groundwork for Conservative opposition to the governments proposals when he asserted that ' $[\mathrm{t}]$ he reason the Prime Minister does not want to wait for the royal commission is clear: he has never intended carrying out proper reform of the House of Lords, but wants to create a house of cronies beholden to him alone'. ${ }^{9}$ This two-pronged line of reasoning continued in the Commons debate on the Queen's Speech, when Sir Norman Fowler argued that the government's intention was 'to introduce an assembly of appointees and placemen: a giant, ermine-clad quango,' which would fail to put pressure on the government because such appointees would be 'very content with their lot,' and contended that it was 'utterly absurd' to proceed with legislation in advance of either the government's white paper or the conclusion of the Royal Commission. ${ }^{10}$

The opposition were also able to make much of the fact that, in the summer of 1998, the government Leader of the House of Lords, Lord Richard, was fired because he was thought to be too strongly in favour of a substantially elected second chamber, and was thus at odds with the prime minister and much of the cabinet. ${ }^{11}$ Conservative MP Kenneth Clarke, for example, was a known advocate of an elected element in the second chamber, but in arguing this case for the reformed Lords, ${ }^{12}$ strategically illustrated the deep divisions within the government regarding the merits of having elected peers in the upper house. This, along with the absence of any coherent plan for what would happen in the putative stage two of reform, set the scene for the legislative process that accompanied the House of Lords Bill.

The House of Lords Bill was formally introduced into the House of Commons on 19 January 1999, but the contentious nature of the legislation had already been revealed well before that date. Throughout 1998, secret talks took place between the Labour and Conservative Leaders in the House of Lords (Lord Richard and Lord Cranborne respectively), at the prompting of the prime minister, aimed at finding some kind of bipartisan approach to reform. ${ }^{13}$ The central fear was that the Conservatives would abandon the Salisbury convention and oppose the legislation in the second chamber, thus causing a scenario in which the government was forced to use the Parliament Acts in order to remove 
the hereditary peers. It was exactly this kind of protracted constitutional battle which the government was keen to avoid. In addition, it was hoped that the secret negotiations would prepare the groundwork for a possible 'big bang' approach to reform whereby the government would delay removing all the hereditary peers in exchange for Conservative support for an at least partly elected second chamber. ${ }^{14}$ However, the complete absence of any united Labour government position with respect to the merits of an elected Lords, and the deep reservations of the prime minister himself on the matter, meant that the talks yielded little by way of an agreed approach on future composition.

Nonetheless, the talks did succeed in mapping a way forward for the elimination of the hereditary peers. Working with Lord Irvine following Lord Richard's sacking, Lord Cranborne promised to neutralise the threat of the Conservative peers destroying the government' reform agenda (by voting down the plans to remove the hereditary peers) in exchange for some of those peers being allowed to remain in the House. By November 1998, Cranborne had secured government agreement on retaining 92 hereditary peers. This comprised 75 (one-tenth of the hereditary peerage) who would be chosen by elections in which only the hereditary peers would be eligible to participate; 15 hereditary peers who were also office holders in the chamber to ensure the efficient functioning of the House during the impending interim period, also chosen by election; and two hereditary officers of state, the Earl Marshal and the Lord Great Chamberlain.

However, Cranborne was caught unawares when his own shadow cabinet refused to support the plan he had worked out with Irvine. ${ }^{15}$ Cranborne, not to be put off, 'smuggled himself into Number 10, to discuss the deal directly with Tony Blair. ${ }^{16}$ That meeting produced final agreement that the Conservative peers would not oppose the government so long as a number of hereditary members could remain in the House of Lords. However, the Leader of the Conservative Party, William Hague, was allegedly in the dark about Cranborne's secret meeting with Blair, and, upon finding out about it, attempted to blow the deal out of the water by exposing it during Prime Minister's Questions on 2 December 1998. This was the first most Labour MPs knew of the deal to retain some hereditary peers, ${ }^{17}$ but the strategy of trying to instigate civil war in the Labour 
Party backfired, because Blair simply pointed out that if some hereditary peers remained, then it was because the Conservative leadership in the Lords has agreed to such a scenario. Blair undermined Hague's attempt to derail the deal by arguing that:

'even when hereditary Conservative peers are prepared to agree to change, the right hon. Gentleman is not. That is the absurd position to which he has reduced himself ... We have the opportunity to reform the House of Lords properly, and to establish a programme that will remove hereditary peers, but will allow us to do that on the broadest possible basis of agreement. It is clear that nowadays, even when we speak to the leader of the Conservative party in the House of Lords, we cannot be sure that the leader of the Conservative party in this House is of the same mind. ${ }^{18}$

What then followed was tantamount to political farce. Although Hague fired Cranborne for agreeing to the deal with Tony Blair without his knowledge or approval, he appointed Lord Strathclyde as his successor, who had not only known about and supported Cranborne's deal, but was instructed by Hague to honour it. Consequently, before legislation had even been introduced into parliament, the entire process was already mired in controversy and the basic task of removing the hereditary peers had become hugely contentious.

Nonetheless, by the time the legislative stages of the House of Lords Bill began, the new Leader of the House of Lords, Baroness Jay, had already secured the cooperation of the crossbench peer, Lord Weatherill, to introduce the agreed amendment to reprieve the 92 hereditary peers agreed by Cranborne and Irvine. Weatherill had been working on his own amendment along similar lines, but was persuaded to substitute it for the Cranborne-Irvine plan instead, on the grounds that his seniority and standing in the Lords would help demonstrate the consensus position which the amendment sought to locate. With the amendment backed by the crossbenches, the Conservative peers would be in a far easier position to abstain from the vote, and thus ensure that the legislation could be secured without undue constitutional fuss. Consequently, the government white paper published in December 1998, which outlined the removal of the hereditary 
peers and the creation of the Royal Commission on future reform, acknowledged that it would accept an amendment to reprieve the 92 peers if it meant that stage one of reform could be secured consensually. ${ }^{19}$

\section{The legislative process in the Commons}

The House of Lords Bill was purposefully short and simple, with the most important clause stating plainly that 'No one shall be a member of the House of Lords by virtue of a hereditary peerage.' The second reading debate took place in the Commons on 1 and 2 February 1999. Although the Leader of the Commons, Margaret Beckett, promoted the bill on the basis of its 'exquisite simplicity' in removing the hereditary peers, ${ }^{20}$ and while many Labour MPs kept their contributions to the limited issue of the hereditary peers, much of the debate nevertheless focused on two problematic issues: first, the politics of the Weatherill amendment to reprieve some of the hereditary peers, and, second, the far more contentious issue of what would follow this stage one of reform.

The basic mechanics of the amendment to allow some hereditary peers to remain proved to be hugely controversial. Margaret Beckett acknowledged the agreement which had been reached to accept an amendment put forward by the crossbenches in the Lords to reprieve 92 peers, and stated that the government was 'minded to accept it' so long as the rest of the government's legislative programme was not frustrated..$^{21}$ However, she also made it plain that the government would not accept a similarly worded amendment if it was moved in the Commons instead. ${ }^{22}$ Ostensibly, the reason for this was to ensure the good behaviour of the House of Lords on the matter. However, the whole question of why the government was permitting the amendment, instead of incorporating it into the legislation at the start, beautifully illustrated the basis of the opposition that the Conservative Party was able to mount against the House of Lords Bill. Its own senior peers had played an integral role in bringing the reprieve amendment about. However, Conservatives in the House of Commons were able to exploit the willingness of the government to allow the second chamber to constrain its constitutional legislation, without courting accusations of incoherence themselves, precisely because the Conservative leadership in the Commons had not been party to the negotiating process. The strange positioning of the 
Conservatives on the matter meant that it was, ironically, the government which found itself in the position of arguing that the hereditary peers were 'utterly, totally, literally, indefensible, ${ }^{23}$ while simultaneously defending the arrangement to keep some of them in place for an interim period of unknown duration.

The second controversial issue which permeated the second reading debate concerned the process of reform following the removal of the hereditary peers. The Conservative MP, John Bercow, for example, asked Margaret Beckett if 'she expects reform to be completed within her remaining political lifetime', to which she replied in the affirmative, ${ }^{24}$ a response which looked shaky at the time, and which looks even shakier a decade on, but which was in fact the only response that could have been offered. Despite Beckett's argument that consideration of stage two could only usefully proceed once the hereditary membership had been dealt with and the impact of the Conservative Party on the second chamber had been at least somewhat reigned in, ${ }^{25}$ the fact remained that this was an entirely new argument fashioned to justify the comprise that had been reached with the Conservative peers and which had never formed part of the Labour government's plans. In this respect, then, the government found itself in tricky political waters throughout the parliamentary process of enacting the House of Lords Bill, principally because the Bill was a compromise which emphatically breached the Labour Party's manifesto commitment. The tone of the Commons debate belied the deep concerns that existed not only across but also within the parties, most notably the Labour Party, whose members had, after all, been under the impression as late as December 1998 that they were going to remove all hereditary peers from the second chamber. The realisation that this was no longer official party policy, at least in the short term, consequently led many Labour MPs to question the veracity of the party's longer-term commitment to Lords reform.

Fundamentally, although the government's political strategy was to separate stage one from stage two, its refusal to state its own preference for what a fully reformed second chamber would ultimately look like, and to then defend that preference, gave much firepower to the opposition parties in the Commons. The government of course explained that it had not indicated a preference because it wanted to wait for the outcome of the Royal Commission inquiry, and that it 
would be insulting to ask it to consider all those matters having stated what the end process should be. ${ }^{26}$ To the extent that the House of Lords Bill was a parliamentary done deal before it was even introduced, the only feasible opposition strategy was to abandon all serious defence of the hereditary principle (the Conservatives had in fact defended the hereditary principle in the House of Lords in the 1997 election campaign), and focus instead on the evident divisions within the Labour Party with respect to the increasingly symbolic stage two. And what the second reading debate demonstrated was the variety of views which existed on the Labour benches about what a fully reformed second chamber should look like in compositional terms. The different kinds of options outlined during the debate are too numerous and diverse to list here, covering a range of combinations of elected and appointed elements, with various arguments forwarded about how an elected membership would impact on the legitimacy of the House, all of which illustrated the difficulty the government could expect if it decided to pursue one single compositional option at some future point without ensuring its own backbenchers were on board. The idea of creating a unicameral parliament was even broached seriously at this time, ${ }^{27}$ an issue which was to have a significant impact on subsequent reform processes. Also under scrutiny was the extent to which the government would adhere to the recommendations of the Royal Commission once its report was published, and whether or not it was useful to have such a Commission if the government planned to pursue a particular reform strategy regardless of what it said ${ }^{28}$ a point made by the former prime minister, John Major on the second day of the debate. On this point, the veteran Labour MP Tony Benn argued that, given the 'immensely complex' deliberations of the Royal Commission and any future Joint Committee, and the 'complex legislation' that would be required to enact compositional reform, there was a genuine fear that the interim House 'will become the permanent solution. ${ }^{29}$ Nonetheless, the important division on the second reading saw a comfortable outcome for the government, and the Bill passed by 381 votes to 135, and passed its third reading debate on 16 March 1999 by 340 votes to 132 . 


\section{The legislative process in the Lords}

Once the House of Lords Bill was safely in the second chamber, where it arrived on 17 March 1999, things became rather more complicated, and it was at this point in the legislative process that the content of the bill underwent the most change. In his opening remarks on the second reading debate, Lord Strathclyde noted that the only certainty about the whole reform process was that "no one expects this Bill in this form to become law, ${ }^{30}$ and continued the Conservatives attack on the legislation on the grounds that it pre-empted the Royal Commission and that the government had to be in a position to state what stage two would involve before embarking on stage one. Strathclyde also softened up the ground for the Weatherill amendment, stating that retaining some hereditary peers would ensure that the government had to complete the reform process, while also placating the Conservative hereditary membership by arguing that the amendment 'falls well short of making the Bill acceptable.' ${ }^{31}$ Lord Weatherill defended the amendment that bore his name on the grounds that it would facilitate stage one, on which the government had a clear manifesto commitment, and it would also 'provide some kind of reassurance of the Government's seriousness of intent to proceed to stage two. ${ }^{, 32}$

However, the Weatherill amendment was not the only issue on which the House of Lords had to reflect. Michael Cockerell, then a BBC journalist observing the removal of the hereditary peers for a documentary series, outlined the work undertaken by the bill team as it attempted to deal with the various amendments put forward by hereditary peers 'who were masters of parliamentary procedure. ${ }^{33}$ Lord Falconer told Cockerell that 'the way the opposition went in the Bill, unlike any other Bill I'd ever seen, was it became an incredibly sort of intense legal debate, with frankly mad legal propositions being advanced.' One of those related to an amendment from Earl Ferrers, about whether the word 'hereditary' should be preceded by 'a' or 'an', with the bill team and the House of Lords having no choice but to commit time to the discussion of such amendments to ensure that the legislation could stand up to legal scrutiny.

Of potentially more importance, though, were two particular issues about the broader implications of the bill with respect to its likely effects, issues which delayed its continued progress. The first related to the language used to refer to 
hereditary peers in the bill, and the legalities of the Writ of Summons. Lord Mayhew of Twysden argued that the language was 'uncertain in its effects and would leave the position of most hereditary Peers uncertain if the Bill was enacted. ${ }^{34}$ The second issue related to whether the House of Lords Bill, once enacted, would breach the provisions of the Treaty of Union 1707. Lord Gray argued that a fundamental element of the Union between England and Scotland was that the latter had hereditary representation in the House of Lords guaranteed by statute, and that if there was no such representation, then the Treaty of Union would be breached. ${ }^{35}$ The House of Lords referred both these matters to the Committee for Privileges. Although this committee decided that there was no case to answer with either of these concerns, ${ }^{36}$ it did not report until after the summer recess, and it was therefore October 1999 before these legal matters had been resolved to the satisfaction of the upper house.

Nonetheless, the effective substance of the House of Lords Bill was altered not only by the government's acceptance of the Weatherill amendment which reprieved 92 hereditary peers, but also because of the nuance of that amendment and its longer term implications. The government, not wishing its short, simple bill to be complicated by electoral arrangements for the reprieved peers, passed the question off to the House of Lords Procedure Committee, which reported in July 1999, and outlined new House standing orders to facilitate the Weatherill amendment provisions. ${ }^{37}$ These new standing orders essentially outlined a series of complex electoral arrangements through which the 15 places for office holders would be elected by all hereditary peers, while the remaining 75 places would be divided up between the parties, and the reprieved peers from each party would be chosen separately by the hereditary peers from those parties. However, the Weatherill amendment also ensured that when a reprieved hereditary peer died, he or she would be replaced by means of a by-election, with the eligible candidates comprising the rest of the expelled peers and the electorate being the hereditary peers of the party in question inside the Lords. This mechanism was pursued in order to ensure that the total number of hereditary peers inside the second chamber remained fixed at 92 until the second stage of reform coulc be secured, and so that the inclusion of the reprieved hereditary peers was not undone over time as they die. 
Donald Shell observed of these electoral mechanisms for the hereditary peers that 'a major measure of constitutional reform has been enacted making provision of such nonsense' and that 'the report of the Lords Procedure Committee that drew up these rules must be considered one of the most hilarious documents ever published by such a body. ${ }^{38}$ Indeed, when reading the Procedure Committee minutes and discussions on this matter, and the various analyses of whether life peers should be permitted to participate in the elections, it is difficult not to think that the whole thing was some kind of constitutional joke. Yet, so keen was the government to get the House of Lords Bill onto the statute book, and so much did it apparently fear that the hereditary peers might well snap around at the last possible moment and the vote the whole thing down, that it was seemingly willing to agree to all kinds of parliamentary foolishness that must surely have had the more seasoned of the hereditary peers doubled over with mirth. Nonetheless, these provisions within the Weatherill amendment ensured that the House of Lords approved the bill at third reading by 221 votes to 81 , with the vast bulk of the Conservative peers abstaining from the vote.

\section{Constitutional and parliamentary consequences}

One of the most bizarre, and certainly unintended, constitutional consequences of the House of Lords Act, which reached the statute books on 11 November 1999, was that it brought a hugely questionable form of democracy into the second chamber, whereby hereditary peers, although excluded by law from sitting and voting in the Lords, could still gain membership of it under that same Act if their hereditary colleagues voted for them either in the elections which took place in 1999 or in a by-election upon the death of one of the reprieved peers. That this arrangement could be put in place, given that the original intentions of the Labour Party were to remove all of the hereditary peers completely, demonstrates the irrational fear which gripped the Labour government after just a year in office. Despite its towering Commons majority, and the obvious use it could make of the rhetoric surrounding its mandate to implement a manifesto commitment, the Labour government nevertheless shrank from proceeding unilaterally even with the limited task of removing the hereditary peers, a task which it was almost impossible to argue against from the perspective of modern representative 
democracy. So eager was it to find consensus, and thus avoid a constitutional impasse which could only be resolved by using the Parliament Acts, that it did not really stop to consider whether there was anything behind the threat from the hereditary peers to hold up the government's legislative programme if it tried to evict them from the second chamber. Given the popularity of the Labour government at that time, it is doubtful whether such a strategy, if utilised, would have resulted in anything other than a huge public backlash against the hereditary peers and an unequivocal government victory with added political capital to boot.

Yet, even after the House of Lords Act was passed, there remained the far more complicated question of what stage two of reform would look like and when it would happen. In the decade after the hereditary peers were expelled from the second chamber, there was no further compositional reform in the House of Lords, despite several attempts to secure it. In casting Lords reform in terms of a two-stage approach, it became inevitable that a major consequence of (partially) securing stage one would be constant questioning about stage two. The Royal Commission on the Reform of the House of Lords reported in January 2000, and recommended a largely appointed chamber. ${ }^{39}$ The report was not well received in the media, ${ }^{40}$ nor was the government's subsequent commitment to a policy in which elected members would be in a minority in a reformed Lords. ${ }^{41}$ In 2002 , the reformist Leader of the House of Commons, Robin Cook, attempted to upend the government's policy on a nominated chamber ${ }^{42}$ by appointing a Joint Committee on Reform of the House of Lords, some six years after it had been promised in the 1997 election manifesto. A House of Commons Public Administration Committee report published in February 2002 had located a 'centre of gravity' amongst MPs for a second chamber that was at least 60 per cent elected. ${ }^{43}$ The Joint Committee was tasked with acting on this finding by formulating a series of options for different kinds of composition, and outlining the various advantages and disadvantages of each, in preparation for parliamentary votes on them which, Cook hoped, would result in a clearly expressed preference of what most MPs would consider to be an acceptable composition in the upper house. The Joint Committee's report, ${ }^{44}$ which outlined seven options ranging from fully appointed to fully elected, and with different mixed proportions in between (for example, 60 per cent elected, 40 per cent 
nominated, and vice versa) was debated in parliament on 4 February 2003. However, the Commons were unable to unite behind any single compositional option in the division, with none of those on offer securing a majority, even although the 80 per cent elected option was defeated by just three votes. ${ }^{45}$ The entire process consequently ended in total farce, and demonstrated not only the anxiety that gripped the Commons about what an elected second chamber might mean for its own democratic legitimacy, but also the extent to which raw politics dictated the outcome of the 2003 vote, with the Conservative Party working specifically in order to embarrass the government over the entire Lords reform affair, and with a significant minority of MPs promoting a unicameral option, the strength of support for which surprised the frontbenches. ${ }^{46}$ Further such embarrassment was secured in March 2007, near the end of the Westminster career of prime minister Tony Blair, when another Commons vote this time backed a 100 per cent and an 80 per cent elected second chamber with majorities of 113 and 38 respectively, although the strategic voting behaviour of MPs in favour of a unicameral parliament also inflated these numbers in order to complicate things for the government. ${ }^{47}$ This support for an elected House was not only a massive reversal of the 2003 outcome, but was also a substantial snub to Blair, whose own preferences for a largely nominated second chamber had stalled progress on stage two throughout his premiership. It also corresponded with the imminent arrival of the new prime minister, Gordon Brown, whose own preferences for an elected chamber were well known. Despite this, it was not until near the end of his premiership that the House of Lords was addressed, in the Constitutional Reform and Governance Bill 2008-09. Yet, this did not seek to take forward stage two, nor even speedily to complete stage one, but instead aimed to secure the far more limited task of ending the process of hereditary peer by-elections, thus facilitating their eventual removal through atrophy. At the time of writing, it remains to be seen whether the government will test the Conservative Party's policy on a predominantly elected chamber by introducing a bill near the end of the parliament that would seek to create just that. ${ }^{48}$

Consequently, although the incoming Labour government in 1997 pledged to remove all the hereditary peers and then consider more fundamental compositional reform, the fact remains that, at the end of their time in office, a 
major point of contention concerns the continued existence of some hereditary peers in parliament and the total lack of political will on the part of government to continue the process of reform. Indeed, had the government been as bold with House of Lords reform as it had been with devolution, the complexion of Westminster would be quite different today, and the basis on which second chamber reform discussions take place would be rather different also.

There is a yet another consequence of the House of Lords Act 1999 which has slightly different implications. To the extent that there was no clearly worked out plan for stage two, opponents of stage one were able to argue during the parliamentary debates that accompanied the House of Lords Act that stripping the hereditary peers from the second chamber left it 'much more in the power of the serving Prime Minister, and would make it a party political machine supporting the Government in power. ${ }^{49}$ The idea that stage one would simply create a House of 'Tony's cronies' which the Labour government would be happy to maintain, because the interim House was a pushover as far as legislation was concerned, was a compelling argument when it was made in 1999, but one which has not turned out to be accurate. Research has demonstrated that, far from becoming a more subservient chamber, the House of Lords has become far more assertive since the removal of most of the hereditary peers, has an increasingly important impact on government policy, and offers far more scrutiny obstacles to legislation than does the House of Commons. ${ }^{50}$ While the issue of how legitimacy is conceived is a difficult one, ${ }^{51}$ the life peers nevertheless seem to feel less encumbered with the hereditary peers removed, and more willing to fulfil the broad range of parliamentary functions ascribed to the second chamber.

This has impacted on the continued debate about what a reformed second chamber should look like in compositional terms. With the House of Lords increasingly demonstrating the valuable task it performs in the legislative process, those opposed to an elected chamber are now in possession of mounting evidence about the capability and utility of an appointed chamber at Westminster, evidence which those who favour an elected House must formulate increasingly convincing arguments against. Therefore, a major consequence of the House of Lords Act 1999, and the two-stage process of reform in which it was embedded, is that it brought about an interim House which was hugely capable of demonstrating its 
functional value. Nonetheless, despite the failure to proceed to stage two, removal of most of the hereditary peers from the second chamber in itself represented a massive constitutional change for Westminster, and proved that parliamentary reform need not always be incremental.

\footnotetext{
${ }^{1}$ Labour Party The New Hope for Britain (London, Labour Party, 1983).

${ }^{2}$ M. Wheeler-Booth 'The House of Lords', in Parliament: Functions, Practice and Procedure, R. Blackburn and A. Kennon (London, Sweet and Maxwell, 2003).

${ }^{3}$ Labour Party It's Time to Get Britain Working Again (London: Labour Party, 1992).

${ }^{4}$ G. Brown 'The servant state: towards a new constitutional settlement', Political Quarterly, 63:4, 394403 (1992).

${ }^{5}$ Labour Party New Labour: Because Britain Deserves Better (London: Labour Party, 1997).

${ }^{6}$ The scale of constitutional legislation pursued in the first session was truly remarkable, including, for example: Referendums (Scotland and Wales) Act 1997, Scotland Act 1997, Government of Wales Act 1998, Northern Ireland (Elections) Act 1998, Regional Development Agencies Act 1998, Greater London Authority Act 1998, Human Rights Act 1998, Bank of England Act 1998. See M. Flinders 'The half-hearted constitutional revolution' in P. Dunleavy, R. Heffernan, P. Cowley and C. Hay (eds.) Developments in British Politics 8 (Basingstoke, Palgrave 2006).

${ }^{7}$ M. Wheeler-Booth 'The House of Lords', p.654.

${ }^{8}$ HL Debs. 24 November 1998, col.4.

${ }^{9}$ HC Debs. 24 November 1998, col.24.

${ }^{10}$ HC Debs. 30 November 1998, cols.560, 564, 565.

${ }^{11}$ D. Shell 'Labour and the House of Lords: a case study in constitutional reform' Parliamentary Affairs, 53:2, 290-310.

${ }^{12}$ HC Debs. 30 November 1998, col.580.

${ }^{13} \mathrm{M}$. Cockerell 'The politics of second chamber reform: a case study of the House of Lords and the passage of the House of Lords Act 1999' Journal of Legislative Studies, 7:1, 119-134.

${ }^{14}$ D. Shell 'Labour and the House of Lords: a case study in constitutional reform' p.298.

${ }^{15}$ D. Shell 'Labour and the House of Lords' p.300; M. Cockerell 'The politics of second chamber reform’ p.124.

${ }^{16} \mathrm{M}$. Cockerell 'The politics of second chamber reform', p.124.

${ }^{17}$ D. Shell 'Labour and the House of Lords' p.300.

${ }^{18}$ HC Debs. 3 December 1998, col.876.

${ }^{19}$ Cm 4183 Modernising Parliament: Reforming the House of Lords, TSO 1998.

${ }^{20}$ HC Debs. 1 February 1999, col.609.

${ }^{21}$ HC Debs. 1 February 1999, col.609.

${ }^{22}$ HC Debs. 1 February 1999, col.610.

${ }^{23}$ HC Debs. 1 February 1999, col.611.

${ }^{24}$ HC Debs. 1 February 1999, col.612.

${ }^{25}$ HC Debs. 1 February 1999, col.616.

${ }^{26}$ HC Debs. 1 February 1999, col.696.

${ }^{27}$ HC Debs. 1 February 1999, col.644.

${ }^{28}$ HC Debs. 2 February 1999, col.746.

${ }^{29}$ HC Debs. 2 February 1999, col.746.
} 


\footnotetext{
${ }^{30}$ HL Debs. 29 March 1999, col.17.

${ }^{31}$ HL Debs. 29 March 1999, col.20.

${ }^{32}$ HL Debs. 30 March 1999, col.215.

${ }^{33} \mathrm{M}$. Cockerell 'The politics of second chamber reform', p.127-8.

${ }^{34}$ HL Debs. 27 July 1999, col.1397.

${ }^{35}$ HL Debs. 27 July 1999, col.1420.

${ }^{36}$ HL 106 First Report of the Select Committee for Privileges, TSO 1998-99; HL 108 Second Report of the Committee for Privileges, TSO 1998-99.

${ }^{37} \mathrm{HC} 81$ Third Report from the Select Committee on Procedure of the House, TSO 1998-99.

${ }^{38}$ D. Shell 'Labour and the House of Lords', p.305.

${ }^{39} \mathrm{Cm} 4534$ A House for the Future, TSO 2000.

${ }^{40}$ A. Kelso Parliamentary Reform at Westminster (Manchester, Manchester University Press 2009), p.162.

${ }^{41}$ Cm 5291 The House of Lords: Completing the Reform, TSO.

${ }^{42}$ R. Cook The Point of Departure (London, Simon and Schuster 2003), p.78.

${ }^{43}$ HC 494 The Second Chamber: Continuing the Reform, Fifth Report from the Select Committee on Public Administration, TSO 2002.

${ }^{44}$ HC 171 House of Lords Reform: First Report from the Joint Committee on Reform of the House of Lords, TSO 2002.

${ }^{45}$ I. McLean, A. Spirling and M. Russell 'None of the above: the UK House of Commons votes on reforming the House of Lords, February 2003' Political Quarterly, 74:3, 298-310, 2003.

${ }^{46}$ A. Kelso Parliamentary Reform at Westminster, p. 175.

${ }^{47}$ A. Kelso Parliamentary Reform at Westminster, p.179.

${ }^{48}$ The Guardian 'Labour bill to reform Lords aimed at wrongfooting Cameron' 21 July 2009.

${ }^{49}$ HC Debs. 1 February 1999, col.643.

${ }^{50}$ M. Russell and M. Sciara 'The policy impact of defeats in the House of Lords' British Journal of Politics and International Relations, 10:4, 571-589 (2008).

${ }^{51}$ A. Kelso 'Reforming the House of Lords: navigating representation, democracy and legitimacy at Westminster' Parliamentary Affairs, 59:4, 563-81.
} 